ISSN 2227-9091

www.mdpi.com/journal/risks

Article

\title{
The Impact of Guarantees on the Performance of Pension Saving Schemes: Insights from the Literature
}

\author{
Alexander Bohnert \\ Department of Insurance Economics and Risk Management, Friedrich-Alexander University \\ Erlangen-Nürnberg (FAU), Lange Gasse 20, 90403 Nürnberg, Germany; \\ E-Mail: alexander.bohnert@fau.de; Tel.: +49-911-5302-884; Fax: +49-911-5302-888.
}

Academic Editor: Nadine Gatzert

Received: 13 July 2015 / Accepted: 16 November 2015 / Published: 20 November 2015

\begin{abstract}
Guarantees are often seen as the key characteristics of pension saving products, but securing them can become costly and is of central relevance especially in the course of the current low interest rate environment. In this article, we deal with the question of how costly the typical types of guarantees are, in the sense that they reduce a pension saving scheme's financial performance over time. In this context, we aim to provide a presentation of insights from selected literature studying the impact of point-to-point guarantees and cliquet-style interest rate guarantees on the performance of pension contracts. The comparative analysis emphasizes that, in most cases, guarantee costs are not negligible with regard to a contract's financial performance, especially compared to benchmarks, and that customers knowingly opt for such guarantees (or not) is, thus, indispensable. To further investigate the willingness-to-pay for guarantees in life insurance is an area for future research, in particular for innovative contract design.
\end{abstract}

Keywords: life insurance; pension saving schemes; guarantees; performance

\section{Introduction}

Against the background of the current low interest rate environment, guarantees are of key importance in pension saving schemes for policyholders and product providers. On the one hand, they provide a minimum payoff at maturity or a minimum interest rate for policyholders, for instance, but on the other hand, they can reduce the performance of the pension product to a substantial extent. We thus focus on 
providing a literature review of articles that study the impact of guarantees on the performance of life insurance and pension products.

In the literature, guarantees in life insurance have attracted widespread attention. In particular, (risk-neutral) valuation of guarantees in pension saving products has been studied extensively forming one important stream of life insurance literature, including contributions, amongst others, by Briys and de Varenne [1], Grosen and Jørgensen [2,3], Tiong [4], Milevsky and Posner [5], Hansen and Miltersen [6], Gerber and Shiu [7], Hardy [8], Tanskanen and Lukkarinen [9], Barbarin and Devolder [10], Siu [11], Guillén, Jørgensen, and Nielsen [12], Gatzert and Kling [13], Ledlie et al. [14], Branger, Mahayni, and Schneider [15], Dong [16], Kling, Ruez, and Russ [17], Schmeiser and Wagner [18], and Goecke [19]. To evaluate guarantees based on risk-neutral valuation techniques assumes replicability of cash flows, which can be viewed as a realistic assumption for product providers, but rather not for customers. Policyholders evaluate guarantees, e.g., based on individual risk preferences, i.e., the willingness-to-pay for a contract and a certain guarantee can be derived through expected utility theory, or empirically by the use of surveys (see Gatzert and Schmeiser [20]). This forms another stream of literature that focuses on the willingness-to-pay for guarantees in life insurance comprising studies, amongst others, by Broeders, Chen, and Koos [21], Gatzert, Huber, and Schmeiser [22], Gatzert, Holzmüller, and Schmeiser [23], Maurer, Rogalla, and Siegelin [24], and Bohnert, Born, and Gatzert [25]. As illustrated in Gatzert and Schmeiser [20], a guarantee's risk-neutral value (lower limit) and the consumers' willingness-to-pay for such a guarantee (upper limit) form a premium agreement range for a market premium.

Gatzert and Schmeiser [20] also provide an overview of life insurance financial products, where they describe innovative pension products along with their guarantees and distinguish their contract design from traditional contracts in life insurance. They further emphasize that it is important for consumers to know about the effects of guarantees on performance figures, in particular for decision-making. Thus, another facet of guarantees is given in their characteristic of influencing the performance of pension saving contracts, which is addressed in several papers. However, a comparative overview of articles that studies the impact of guarantees on the performance of life insurance contracts is still due.

In this paper, we aim to fill this gap and contribute to the literature by providing a comparative review of studies that investigate the impact of guarantees on the performance of pension saving contracts. We, thereby, take two typical guarantees in traditional and innovative life insurance into account, which comprise cliquet-style and point-to-point guarantees. In this comparative overview, we consider the contributions by Gatzert and Schmeiser [26], Jørgensen and Linnemann [27], Faust, Schmeiser, and Zemp [28], Graf, Kling, and Russ [29], Gatzert [30], Guillén et al. [31,32], and Mahlow, Schmeiser, and Wagner [33]. Our study shows that there are two different approaches in the literature how to assess the performance of pension saving contracts with guarantees. The review further demonstrates that the price of a guarantee in terms of lost returns of a pension product can be of considerable relevance. While in the case of a pension saving contract with a money-back guarantee (point-to-point guarantee), the outperformance of a benchmark contract substantially depends on the chosen risk and performance measure, the papers' results with respect to cliquet-style guarantees are more clear-cut. Pension saving contracts with cliquet-style guarantees are outperformed by their benchmark portfolios in most cases in the considered studies. 
The remainder of the paper is structured as follows. Section 2 illustrates the article selection process, specifies and classifies how performance of pension products is measured in the literature and gives an overview of the relevant pension saving contracts. Section 3 provides the comparative review of the selected articles that assess the impact of guarantees on the performance of pension saving products and Section 4 summarizes and gives concluding remarks.

\section{Methodology and Analysis}

As previously indicated, the aim of this paper is to assess the impact of guarantees in pension saving products on their performance based on the literature. In order to fulfill this research question, we start out by conducting a systematic literature review to provide a selection of relevant articles.

\subsection{Literature Review}

In what follows, we describe the article selection process leading to our choice of relevant articles that are examined in more depth subsequently. First of all, we draw our attention to relevant journals in the field of risk and insurance and actuarial science (journal selection). Out of the universe of the finance literature, 14 relevant journals were identified with the help of ABS and VHB rankings and journal lists. The selection of relevant journals comprises (in alphabetical order) Annals of Actuarial Science, Astin Bulletin, European Actuarial Journal, Geneva Papers on Risk and Insurance-Issues and Practice, Geneva Risk and Insurance Review, Insurance: Mathematics and Economics, Journal of Risk, Journal of Risk and Insurance, Journal of Risk Finance, North American Actuarial Journal, Risk Management and Insurance Review, Risks, Scandinavian Actuarial Journal, and Zeitschrift für die gesamte Versicherungswissenschaft. To identify potential publications in the relevant journals, the databases Web of Science [34] and Google Scholar [35] are used and we did not apply any restrictions with respect to the time horizon for the selection of papers. The systematic article selection process resulted in eight articles that are further classified and examined in the following sections and is illustrated in Table 1.

Table 1. Summary of the article selection process.

\begin{tabular}{cccc}
\hline Database/Source & Web of Science & Google Scholar & Manual Search \\
\hline & In topic & In papers & - \\
\cline { 2 - 4 } Keywords & "performance" and any of the words & - \\
& "guarantee"/"pension"/"life insurance" & - \\
\hline Number of papers & 91 & 2085 & 1 \\
After screening process & 2 & $5 *$ & *
\end{tabular}

Table 1 shows the article selection process consisting of two steps. First, online databases are used to scan the journals for relevant articles that contain defined keywords as search criteria and supplemented by a manual search for working papers at relevant institutions. The set of keywords consists of the word "performance" in combination with any of the words "guarantee"/"pension"/"life insurance". While in the case of the Web of Science [34] database, these keywords are searched for in the topic of the article, i.e., in an article's title, keywords, and abstract, resulting to about 90 papers. In the case of the 
Google Scholar [35] database the keywords can appear anywhere in the paper, i.e., in all text, which results to about 2000 potential papers. In a second step, these potential papers were manually scanned based on their title to identify the relevant articles for our research question leading to eight papers after this screening process (including the result of the manual search) that are classified and studied in more depth in the subsequent section.

\subsection{Performance Measurement of Pension Saving Schemes}

The final sample of eight articles is then examined more closely and classified according to two major characteristics, namely the type of guarantee under study and the performance measurement approach. The results show that, primarily, two major types of guarantees are analyzed explicitly or implicitly by the papers with respect to their impact on product performance comprising cliquet-style guarantees and point-to-point guarantees, which we focus on in what follows. First, cliquet-style guarantees (in the form of interest rate guarantees) that have been the predominant guarantee type in traditional life insurance contracts are considered, and second, point-to-point guarantees (as money-back guarantees) that play an important role in numerous innovative contract designs are studied (see, e.g., Gatzert and Schmeiser [20]).

A next criterion to classify the papers is the performance measurement approach. The considered studies exhibit that performance and the reduction in performance due to a guarantee are measured by approaches that can be divided into two groups. The one approach calculates the distribution of maturity payoffs and applies several performance and risk measures, whereas the other approach determines internal rates of return (IRR) of a pension product that are compared to the corresponding rates of a trivial benchmark strategy. A first overview providing the studies and their classifications with respect to performance measurement (and the two fundamental types of guarantees) is given in Table 2.

The first approach (left column in Table 2) calculates the distribution of a contract's payoff at the end of the accumulation phase under the real-world measure $P$ (see, e.g., Gatzert and Schmeiser [26]). ${ }^{1}$ These payoff distributions are calculated for different products or product versions containing different types of guarantees. On the basis of the payoff distribution, several risk and performance measures are calculated to enable a comparison of different guarantee schemes. These risk measures include, inter alia, the mean and standard deviation, and several quantiles of the payoff distribution (see, e.g., Gatzert and Schmeiser [26]; Jørgensen and Linnemann [27]; Faust, Schmeiser, and Zemp [28]). Performance measures, such as the Sharpe ratio, the omega, and the Sortino ratio, are determined, which are in line with maximizing expected utility for an individual decision-maker (see, e.g., Gatzert and Schmeiser [26]). Furthermore, internal rates of return are computed, e.g., based on the mean payoff or for different quantiles of the payoff distribution (see Graf, Kling, and Russ [29]). To make different products containing possibly different guarantee types comparable, two different approaches are applied. First, different contracts are calibrated that their guarantee costs calculated under the risk-neutral measure $Q$ are equal for different types of guarantees (see, e.g., Gatzert and Schmeiser [26]) and second, risk-neutral guarantee costs are charged as guarantee fees and, thus, subtracted from a contract's account value (see, e.g., Graf, Kling, and Russ [29]). The impact of guarantees on the performance of pension

1 The case of the decumulation phase is considered in Jørgensen and Linnemann [27], where the distribution of the annual payouts is determined. 
contracts is, thus, assessed by comparing the contracts with and without different guarantees by means of the risk and performance measures. In addition to this, tests for stochastic dominance are conducted (see, Gatzert and Schmeiser [26]; Graf, Kling, and Russ [29]).

Table 2. Approaches to assess the performance of pension saving schemes with and without different types of guarantees.

\begin{tabular}{|c|c|}
\hline $\begin{array}{l}\text { Risk and Performance Measures } \\
\text { Applied to Payoff Distribution }\end{array}$ & $\begin{array}{l}\text { Internal Rates of Return (IRR) Compared } \\
\text { to an Equivalent Trivial Benchmark }\end{array}$ \\
\hline $\begin{array}{l}\text { Gatzert and Schmeiser [26]*,b } \\
\text { Jørgensen and Linnemann [27] }{ }^{\mathrm{a}} \\
\text { Faust, Schmeiser, and Zemp [28] **,a } \\
\text { Graf, Kling, and Russ [29] *,b } \\
\text { Gatzert [30] }{ }^{\mathrm{b}} \\
\text { Mahlow, Schmeiser, and Wagner [33] }]^{\mathrm{a}, \mathrm{b}}\end{array}$ & $\begin{array}{l}\text { Guillén et al. [31] }{ }^{\mathrm{b}} \\
\text { Guillén et al. [32] }\end{array}$ \\
\hline
\end{tabular}

The second approach (right column in Table 2) calculates the difference between the yearly internal rate of return of the pension saving product and the corresponding yearly internal rate of return of a trivial benchmark strategy that is equivalent to the considered contract in terms of a predefined risk measure. This approach is introduced in Guillén et al. [31], where they consider a pension saving contract with its accumulation and decumulation phase. Fixed contributions during the accumulation phase and fixed annuity payments during the decumulation phase (decreasing annuity payments alternatively) are assumed, while mortality and surrender effects are ignored. More precisely, the pension saving contract's payoff distribution at the final age, i.e., at maturity after accumulation and decumulation phase, is calculated under the real-world measure $P$ along with the value at risk and conditional value at risk, respectively. Then, a trivial portfolio is constructed that consists of bonds and stocks with a stock portion (constant stock portion throughout the contract term) leading to the same risk as the pension product according to the chosen risk measure. This portfolio is denoted as an equivalent trivial benchmark portfolio. Based on the payoffs' medians (alternatively means) at maturity of the considered contract and its trivial benchmark, the yearly internal rates of return are calculated and subtracted from each other. This provides a yearly financial loss or gain of the considered product compared to its trivial benchmark. As an alternative risk measure to determine the benchmark portfolio, the price of a point-to-point guarantee against a negative payoff at maturity, i.e., money-back guarantee, is considered. This guarantee has to be calculated under the risk-neutral measure $Q$ for both types of contracts, i.e., for the pension product and its trivial benchmark.

\subsection{Overview of Considered Products in the Selected Literature}

We next present and classify the products that are considered in our sample of articles and clarify their link to pension savings, an illustration is given in Table 3. However, we cannot go beyond short descriptions of the products or product classes, otherwise it would exceed the scope of the paper. 
We, thus, refer the reader directly to the corresponding papers for further details (in particular for mathematical definitions). It can be seen that the papers comprise various types of savings contracts from (partial) mutual fund investments with and without different types of guarantees to traditional life insurance products containing a saving process with a minimum interest rate guarantee and a bonus distribution scheme. First, we classify the considered contracts according to their embedded guarantees comprising cliquet-style guarantees, point-to-point guarantees, high watermark or lookback guarantees, and the case where no guarantee is applied.

In case of the cliquet-style guarantees or interest rate guarantees, three different product types can be found in the papers, namely a mutual fund investment with a yearly interest rate guarantee (see Gatzert and Schmeiser [26]), participating life insurance contracts (see Faust, Schmeiser, and Zemp [28]; Jørgensen and Linnemann [27]; Guillén et al. [32]; and Mahlow, Schmeiser, and Wagner [33]), and a Danish formula based smoothed investment-linked annuity scheme called TimePension (see Jørgensen and Linnemann [27]; and Guillén et al. [31]). Traditional participating life insurance contracts or also called traditional with-profits products have been a prominent way for pension savings and are available in several countries, e.g., in Denmark or Germany (see Faust, Schmeiser, and Zemp [28]; and Jørgensen and Linnemann [27]), where some specifics differ due to different national regulations. However, the basic product is very similar in essence. Policyholders participate in the collective savings process of a life insurance company through an insurance contract that guarantees a minimum interest rate guarantee every year and they have the right to receive surplus (bonus entitlement). Once surplus in one year is credited to the contract, this surplus amount is also subject to the interest rate guarantee, see, e.g., Bohnert and Gatzert [37]. Mahlow, Schmeiser, and Wagner [33] consider insurance contracts that qualify for the German government subsidization, i.e., these are called Riester contracts, but their Riester life insurance contract resembles typical participating life insurance contracts.

The Danish product TimePension combines the ideas of traditional participating life insurance contracts with pure unit-linked policies. While in case of traditional participating life insurance contracts, the total interest rate (guaranteed rate plus surplus) is set by the management for each year, TimePension contains a mathematically well-defined formula to calculate the total yearly return for a contract, i.e., it controls the distribution of generated funds to the two accounts. There are two accounts for TimePension, namely an individual account for each policyholder and a smoothing or buffer account belonging to all policyholders and the company, respectively (for a mathematical definition, see, e.g., Guillén, Jørgensen, and Nielsen [12]). In a strict sense, this guarantee can be seen as a further type of guarantee, but we classify it to cliquet-style guarantees, since there are similarities. 
Table 3. Overview of considered products in the selected literature.

\begin{tabular}{ccc}
\hline \multicolumn{1}{c}{ Product (Class) } & Product Name & Article \\
\hline \multirow{2}{*}{ Cliquet-style guarantee } & & \\
\hline Mutual fund with interest rate guarantee & & Gatzert and Schmeiser [26] \\
\hline \multirow{2}{*}{ Participating life insurance } & German traditional participating life insurance & Faust, Schmeiser, and Zemp [28] \\
\cline { 2 - 3 } & Traditional with-profits life insurance contract & Jørgensen and Linnemann [27] \\
\cline { 2 - 3 } & Danish with-profit life insurance contract & Guillén et al. [32] \\
\cline { 2 - 3 } & Riester life insurance contract & Mahlow, Schmeiser, and Wagner [33] \\
\hline Danish formula based smoothed & & Jørgensen and Linnemann [27] \\
investment-linked annuity scheme & TimePension & Guillén et al. [31]
\end{tabular}

\section{Point-to-point guarantee}

\begin{tabular}{ccc}
\hline & Static option based product & Graf, Kling, and Russ [29] \\
\cline { 2 - 3 } Mutual fund with money-back guarantee & Mutual fund with money-back guarantee & Gatzert [30] \\
\cline { 2 - 3 } & $\begin{array}{c}\text { Riester fund product with a full } \\
\text { money-back guarantee }\end{array}$ & Mahlow, Schmeiser, and Wagner [33] \\
\hline
\end{tabular}

Zero-bond plus underlying

Constant proportion portfolio insurance

Graf, Kling, and Russ [29]

on client individual basis (iCPPI)

\section{High watermark/lookback guarantee *}

\begin{tabular}{ccc}
\hline Mutual fund with lookback guarantee & - & Gatzert and Schmeiser [26] \\
\hline $\begin{array}{l}\text { CPPI implemented in mutual } \\
\text { fund (CPPI high watermark) }\end{array}$ & - & Graf, Kling, and Russ [29] \\
\hline
\end{tabular}

\section{No guarantee}

\begin{tabular}{|c|c|c|}
\hline \multirow{14}{*}{ Mutual fund } & Mutual fund & \multirow{2}{*}{ Faust, Schmeiser, and Zemp [28] } \\
\hline & Exchange-traded fund & \\
\hline & Pure unit-linked policy & Jørgensen and Linnemann [27] \\
\hline & Equity fund $* *$ & \multirow{3}{*}{ Graf, Kling, and Russ [29] } \\
\hline & Balanced fund ** & \\
\hline & Life-cycle fund ** & \\
\hline & Mutual fund without guarantee & Gatzert [30] \\
\hline & United linked ** & \multirow{6}{*}{ Guillén et al. [31] } \\
\hline & Stocks $50 * *$ & \\
\hline & MarketPension ** & \\
\hline & Danica $* *$ & \\
\hline & Nordea $* *$ & \\
\hline & PFA ** & \\
\hline & Non-Riester fund product & Mahlow, Schmeiser, and Wagner [33] \\
\hline
\end{tabular}

Notes: * these two products are subsequently addressed together with the group of point-to-point guarantees;

** mutual funds themselves invest in stocks and bonds and differ with respect to their stock portion over time. 
In case of the point-to-point guarantees, there is one major group of products consisting of a mutual fund combined with a full or partial money-back guarantee that are secured via options (see, e.g., Graf, Kling, and Russ [29]; Gatzert [30]; and Mahlow, Schmeiser, and Wagner [33]). Two further products considered in Graf, Kling, and Russ [29] secure a money-back guarantee via constant proportion portfolio insurance (CPPI) or an investment in a zero-bond. Next, the high watermark or lookback guarantees in mutual funds in Gatzert and Schmeiser [26] and Graf, Kling, and Russ [29] are also secured via options or a CPPI strategy, respectively.

For comparison reasons and to measure the impact of guarantees on the performance of a pension saving product, the papers consider benchmark investments without guarantees. The products here basically differ with respect to their cost structure or the mutual fund's stock portion over time. Faust, Schmeiser, and Zemp [28] include two different types of mutual funds without guarantees, namely a mutual fund with a higher cost structure and an exchange-traded fund with a lower cost structure. Graf, Kling, and Russ [29] include three different fund investments that differ in their riskiness, i.e., their stock portion over time, which are denoted as equity fund, balanced fund, and life-cycle fund. Guillén et al. [31] consider several different mutual fund investments that, inter alia, mimic investment strategies of funds that are available at the Danish market (united linked, stocks 50, MarketPension, Danica, Nordea, and PFA). These contracts do not contain a guarantee per se, but in their performance measurement approach, where contracts are calibrated based on risk measures, they apply a money-back guarantee as risk measure for all considered contracts (including TimePension).

\section{The Impact of Guarantees on the Performance of Life Insurance Contracts}

We next present selected articles that measure and compare the performance of pension saving schemes without and with guarantees, while we focus on cliquet-style and point-to-point guarantees representing typical guarantees in traditional and innovative life insurance.

\subsection{Cliquet-Style Guarantees: The Case of Traditional Participating Life Insurance}

Four articles are considered that analyze, inter alia, cliquet-style guarantees in traditional life insurance contracts with respect to their impact on the performance of the contracts. Jørgensen and Linnemann [27] and Guillén et al. [32] study the case of Denmark, whereas Faust, Schmeiser, and Zemp [28] and Mahlow, Schmeiser, and Wagner [33] focus on Germany. An overview of the articles containing information on the considered products and guarantees, some analysis characteristics, the performance measurement approach, and some key findings is provided in Table 4. 
Table 4. Cliquet-style guarantees in traditional life insurance and their impact on performance: Insights from the literature.

\begin{tabular}{|c|c|c|c|c|c|}
\hline Article & Products and Guarantees & Some analysis Characteristics & Performance Measurement & Some Key Findings & Outperformed * \\
\hline $\begin{array}{c}\text { Jørgensen and } \\
\text { Linnemann [27] }\end{array}$ & $\begin{array}{l} \\
\\
\\
\text { - } \text { Traditional with-profits } \\
\text { life insurance contract } \\
\text { (interest rate guarantee } \\
\text { and return smoothing) } \\
\text { - Pure unit-linked policy } \\
\text { (no guarantee) } \\
\text { - } \text { TimePension } \\
\text { (a Danish formula based smoothed } \\
\text { investment-linked annuity scheme) }\end{array}$ & $\begin{array}{l}\text { - Consider accumulation and } \\
\text { decumulation phase with focus } \\
\text { on payoff distribution in } \\
\text { decumulation phase } \\
\text { - Costs, mortality, and surrender } \\
\text { are not taken into account } \\
\text { - Buffer effects are not taken into } \\
\text { account, i.e., model constructed } \\
\text { "generation neutral" }\end{array}$ & $\begin{array}{l} \\
\text { - Simulation of payoff } \\
\text { distribution in the } \\
\text { decumulation phase under the } \\
\text { real-world measure } P \\
\text { - Comparison of mean payoff } \\
\text { and different quartiles (5\%, } \\
\text { 50\%, and 95\%) of the payoff } \\
\text { distribution in the } \\
\text { decumulation phase } \\
\text { - Variability measurement: } \\
\text { Standard deviation, minimum, } \\
\text { and maximum of the annual } \\
\text { pension benefit adjustment }\end{array}$ & $\begin{array}{l}\text { - Traditional with-profits life insurance } \\
\text { contract is outperformed by benchmarks } \\
\text { (i.e.,. unit-linked policy and } \\
\text { TimePension), except for worst } \\
\text { market scenarios } \\
\text { - Pension benefits provided by the } \\
\text { traditional scheme and TimePension are } \\
\text { similar with respect to stability and both } \\
\text { products are considerably more stable } \\
\text { than the unit-linked product } \\
\text { - TimePension provides more upside } \\
\text { potential than the two other contracts } \\
\text { for the given set of parameters } \\
\text { (TimePension allows for a higher stock } \\
\text { portion due to its smoothing mechanism } \\
\text { with its "loss-limiting effect") } \\
\text { - Traditional scheme performs best } \\
\text { in the worst market scenarios (i.e., } \\
\text { with respect to } 5 \% \text { quantile of the } \\
\text { size of pension benefits): Attractive } \\
\text { for high risk-averse policyholders } \\
\text { - TimePension performs best in all other } \\
\text { market scenarios (i.e., with respect to } \\
50 \% \text { and } 95 \% \text { quantile and average) and } \\
\text { combines stability of pension benefits } \\
\text { (comparable to the traditional scheme) } \\
\text { with upside potential in the payout phase }\end{array}$ & $\begin{array}{l}\text { - Yes/No } \\
\text { (depending on } \\
\text { the risk } \\
\text { measure) }\end{array}$ \\
\hline
\end{tabular}


Table 4. Cont.

\begin{tabular}{|c|c|c|c|c|c|}
\hline Article & Products and Guarantees & Some analysis Characteristics & Performance Measurement & Some Key Findings & Outperformed * \\
\hline $\begin{array}{l}\text { Faust, } \\
\text { Schmeiser, and } \\
\text { Zemp [28] }\end{array}$ & $\begin{array}{l}\text { - German traditional } \\
\text { participating life insurance } \\
\text { (PLI) with cliquet-style interest } \\
\text { rate guarantee and bonus } \\
\text { distribution scheme in the } \\
\text { accumulation phase } \\
\text { - Mutual fund (MF) } \\
\text { (no guarantee) } \\
\text { - Exchange-traded fund (ETF) } \\
\text { (no guarantee) }\end{array}$ & $\begin{array}{l}\text { - PLI is decomposed in term life } \\
\text { insurance and savings part } \\
\text { - Only accumulation period is } \\
\text { considered; include embedded } \\
\text { options, bonus distribution } \\
\text { (based on Kling, Richter, } \\
\text { and Russ [38]), and } \\
\text { management discretion } \\
\text { - Account for generation } \\
\text { cross-subsidization effects } \\
\text { - Death benefit is not included in } \\
\text { the comparison } \\
\text { - Cost are taken into account for } \\
\text { the different types of products }\end{array}$ & $\begin{array}{l}\text { - Performance measurement is } \\
\text { based on Gatzert and } \\
\text { Schmeiser [26] } \\
\text { - Simulation of the payoff } \\
\text { distribution at maturity of PLI } \\
\text { savings part, MF, and ETF } \\
\text { under the real-world measure } P \\
\text { - Comparison of mean payoff } \\
\text { and different quantiles (5\%, } \\
25 \%, 50 \%, 75 \% \text {, and } 95 \%) \text { of } \\
\text { the final payoff distribution } \\
\text { - Performance measures: Sharpe } \\
\text { ratio, omega, and Sortino ratio }\end{array}$ & $\begin{array}{l}\text { - Traditional participating life insurance } \\
\text { is outperformed by the benchmarks (MF } \\
\text { and ETF) for low initial surplus fund } \\
\text { - Insurer's initial reserve } \\
\text { situation and management } \\
\text { discretion have a considerable } \\
\text { impact on the payoff distribution } \\
\text { - ETF payoff distribution is best compared } \\
\text { to PLI and MF with respect to the } \\
\text { performance measures considered } \\
\text { (Sharpe ratio, omega, and Sortino ratio) } \\
\text { - In case of a high level of the initial } \\
\text { surplus fund: PLI is better than } \\
\text { for MF and vice versa } \\
\text { in case of a low initial surplus fund }\end{array}$ & $\begin{array}{l}\text { - Yes/no } \\
\text { (depending on } \\
\text { the initial } \\
\text { buffer } \\
\text { situation } \\
\text { and the } \\
\text { benchmark) }\end{array}$ \\
\hline
\end{tabular}


Table 4. Cont.

\begin{tabular}{|c|c|c|c|c|c|}
\hline Article & Products and Guarantees & Some analysis Characteristics & Performance Measurement & Some Key Findings & Outperformed * \\
\hline Guillén et al. [32] & $\begin{array}{l}\text { - Danish with-profit life } \\
\text { insurance contracts that include } \\
\text { a minimum interest rate } \\
\text { guarantee (contracts by Codan, } \\
\text { Danica, PFA, and Tryg) }\end{array}$ & $\begin{array}{l}\text { - Study includes accumulation } \\
\text { and decumulation phase } \\
\text { - Minimum interest rate } \\
\text { guarantee is decomposed in } \\
\text { three components (denoted as } \\
\text { "blows"): (1) with-profit } \\
\text { mechanism does not } \\
\text { outperform a trivial } \\
\text { benchmark, (2) the guarantee } \\
\text { requires a risk premium, and } \\
\text { (3) policyholders become more } \\
\text { risk averse due to the saving } \\
\text { loss of the product } \\
\text { - Analysis refrains from } \\
\text { modeling buffer effects, i.e., } \\
\text { initial buffer equals target } \\
\text { buffer level (buffer effects } \\
\text { could be blow number } 4 \text { ) } \\
\text { - Surplus distribution is based on } \\
\text { Grosen and Jørgensen [3] } \\
\text { - Costs, mortality, and surrender } \\
\text { are not taken into account }\end{array}$ & $\begin{array}{l}\text { - Performance measurement is } \\
\text { based on Guillén } \text { et al. [31] } \\
\text { - Payoff distributions under the } \\
\text { real-world measure } P \text { are } \\
\text { calculated of a with-profits } \\
\text { policy and a trivial benchmark } \\
\text { strategy (with a fixed stock } \\
\text { and bond portion) that are } \\
\text { equal with respect to the } \\
\text { expected shortfall } \\
\text { - Based on the distribution's } \\
\text { median, internal rates of return } \\
\text { are calculated and compared }\end{array}$ & $\begin{array}{l}\text { - The price of minimum interest rate } \\
\text { guarantees can be up to a financial } \\
\text { loss in returns of } 0.87 \% \text { per year for } \\
\text { an expected shortfall level of } 95 \% \\
\text { - This financial loss in returns is larger for } \\
\text { higher interest rate guarantees } \\
\text { - The with-profits policies on the } \\
\text { Danish life insurance market } \\
\text { do not considerably differ with } \\
\text { respect to the underperformance } \\
\text { of the benchmark strategies } \\
\text { - Results would have been worse, if initial } \\
\text { low buffer levels (the case of } 2012 \\
\text { in Denmark) would have been } \\
\text { included in the analysis } \\
\text { - Interest rate guarantees are only a } \\
\text { meaningful product feature for } \\
\text { policyholder that are extremely risk } \\
\text { averse, e.g., at a risk level of } 99.9 \%\end{array}$ & - Yes \\
\hline
\end{tabular}


Table 4. Cont.

\begin{tabular}{|c|c|c|c|c|c|}
\hline Article & Products and Guarantees & Some analysis Characteristics & Performance Measurement & Some Key Findings & Outperformed * \\
\hline $\begin{array}{l}\text { Mahlow, } \\
\text { Schmeiser, } \\
\text { and Wagner [33] }\end{array}$ & $\begin{array}{l}\text { - Riester life insurance contracts } \\
\text { with an interest rate guarantee } \\
\text { and surplus participation } \\
\text { (cliquet-style guarantee) } \\
\text { - Riester fund products with a } \\
\text { full money-back guarantee } \\
\text { (point-to-point guarantee) } \\
\text { - Non-Riester fund products } \\
\text { (no guarantee) }\end{array}$ & $\begin{array}{l}\text { - Only accumulation phase } \\
\text { - Subsidization effects (tax } \\
\text { benefits, grants by the } \\
\text { government) are not included } \\
\text { - Contracts' cost structures are } \\
\text { modeled in detail based on } \\
\text { market data } \\
\text { - Surrender and mortality are } \\
\text { taken into account in terms of } \\
\text { fixed ratios per year } \\
\text { - Surplus distribution rate for the } \\
\text { life insurance is assumed to be } \\
\text { normally distributed calibrated } \\
\text { with market data } \\
\text { Modeling parameters for the } \\
\text { different products are based on } \\
\text { historical values for the } \\
\text { corresponding product type and } \\
\text { for several providers }\end{array}$ & $\begin{array}{l}\text { - Payoff distributions of the three } \\
\text { product types for different } \\
\text { settings are simulated under the } \\
\text { real-world measure } P \text { for a } \\
\text { model parameterization based } \\
\text { on market data } \\
\text { - Cumulated embedded costs are } \\
\text { studied for the products } \\
\text { - Payoff distributions are } \\
\text { compared by means of } \\
\text { quantiles (10\%, } 50 \% \text {, and } \\
\text { 90\%), the mean payoff, and the } \\
\text { performance risk measures } \\
\text { Sharpe and Sortino ratio }\end{array}$ & $\begin{array}{l}\text { - Performance measures (Sharpe ratio and } \\
\text { Sortino ratio) are best for the non-Riester } \\
\text { fund products (no guarantee), second } \\
\text { best for the Riester fund products with a } \\
\text { full money-back guarantee (point-to- } \\
\text { point guarantee), and worst for the } \\
\text { Riester life insurance contracts with an } \\
\text { interest rate guarantee and surplus } \\
\text { participation (cliquet-style guarantee) } \\
\text { - The quantiles illustrate the } \\
\text { low volatility and stable payoffs } \\
\text { of the life insurance contracts } \\
\text { compared to the other fund products } \\
\text { - The cost ratio, i.e., accumulated costs } \\
\text { related to the mean payoffs, is highest for } \\
\text { the Riester life insurance contracts }\end{array}$ & - Yes \\
\hline
\end{tabular}

Notes: * indicates that a product with a cliquet-style guarantee is outperformed by the considered benchmarks products (see column "some key findings" for more details). 
As can be seen from Table 4, all considered papers study the pension saving schemes' performance for the contracts' accumulation phases. While Faust, Schmeiser, and Zemp [28] and Mahlow, Schmeiser, and Wagner [33] focus on the accumulation phase only, Jørgensen and Linnemann [27] and Guillén et al. [32] do additionally integrate the decumulation phase into their analyses. However, the decumulation phase is assumed to have a fixed term to maturity, where mortality and surrender are not accounted for. In general, mortality and surrender effects have not been modeled by Jørgensen and Linnemann [27], Faust, Schmeiser, and Zemp [28], and Guillén et al. [32]. In contrast to this, Mahlow, Schmeiser, and Wagner [33] consider mortality and surrender in their model framework by applying mortality and surrender ratios over time based on market data. Furthermore, the considered papers differ in their way of handling possible fees and charges. While Jørgensen and Linnemann [27] and Guillén et al. [32] refrain from modeling fees, Faust, Schmeiser, and Zemp [28] do include different fees for the considered types of contracts, and Mahlow, Schmeiser, and Wagner [33] model fees and charges in detail based on market data for selected and representative insurance companies. Mahlow, Schmeiser, and Wagner [33] further study Riester contracts that are subsidized by the German government, but for comparability reasons they do not include government grants or tax benefits in their analysis.

Next, surplus distribution with the surplus fund (buffer) level at inception of a traditional participating life insurance contract can have a considerable impact on the contract's financial performance over time. While all considered papers except for Faust, Schmeiser, and Zemp [28] do exclude buffer effects from the analysis, Faust, Schmeiser, and Zemp [28] compare several different contract generations including the cases, where the surplus fund is empty at contract inception or completely filled with a target buffer rate. With respect to surplus distribution, Jørgensen and Linnemann [27] apply an approach that the bonus smoothing is "generation neutral" but omit details of the model. While, Guillén et al. [32] model their bonus distribution based on Grosen and Jørgensen [3], Mahlow, Schmeiser, and Wagner [33] assume the contracts' surplus distribution rates to be normally distributed and calibrated with market data. Faust, Schmeiser, and Zemp [28] model the bonus distribution based on Kling, Richter, and Russ [38].

As further can be seen from Table 4, all considered studies indicate that pension saving products with cliquet-style guarantees are outperformed by most of their benchmark products in terms of the considered and different performance measurement approaches. Jørgensen and Linnemann [27], Faust, Schmeiser, and Zemp [28], and Mahlow, Schmeiser, and Wagner [33] each consider a contract including a cliquet-style guarantee and different benchmark products for which they calculate several risk and performance measures based on the different considered contracts' simulated payoff distributions (first approach in Table 2). They thereby use typical alternative pension saving products as benchmarks. Jørgensen and Linnemann [27] use a pure unit-linked contract (without any guarantee) and the Danish formula-based smoothed investment-linked annuity called TimePension as benchmarks. Faust, Schmeiser, and Zemp [28] use a mutual fund and exchange-traded fund as benchmarks, which do not feature any guarantee and which differ with respect to their fees and charges. Mahlow, Schmeiser, and Wagner [33] compare the product featuring a cliquet-style guarantee to fund product with a full money-back guarantee (point-to-point guarantee) and a fund product without any guarantee. In contrast to this, Guillén et al. [32] follow the second approach and calculate internal rates of return of the considered pension products with cliquet-style guarantees, which are compared to the internal rates of return of an equivalent trivial benchmark strategy leading to the same risk under a given risk measure (see also Table 2). They, thereby, compare four Danish with-profit life insurance contracts that include 
a minimum interest rate guarantee to their trivial benchmarks and find that all of these with-profit policies are outperformed by their equivalent trivial benchmark portfolios.

We next present the papers more closely including their model framework and some of their key findings. Jørgensen and Linnemann [27] compare the performance of a traditional with-profits scheme to a pure unit-linked contract and a formula based smoothed investment-linked annuity scheme that was first introduced in the Danish market in 2002 with the name "TimePension" (see Guillén, Jørgensen, and Nielsen [12]; Linnemann, Bruhn, and Steffensen [39]). They, thereby, take both, the accumulation as well as the decumulation phase into account. The with-profits scheme comprises a cliquet-style interest rate guarantee along with a bonus distribution mechanism and virtually resembles a deferred annuity contract with a fixed payout phase, i.e., mortality effects are ignored to make the contracts comparable. In contrast to this, the unit-linked policy does not include any type of guarantee and in case of TimePension, a mathematically pre-defined surplus smoothing scheme is applied that does not involve an interest rate guarantee (here, the annual interest rate that is credited to the savings account is also allowed to be negative in bad years).

To compare the three types of contracts, the payoff distribution is calculated under the real-world measure $P$ for each year in the payout phase (35 years accumulation phase and 20 years decumulation phase). However, the products' asset allocations vary with respect to stocks and bonds, i.e., the stock portion for the traditional contract is $25 \%, 35 \%$ for the unit-linked product, and $50 \%$ for TimePension. Thus, the average pension benefits are highest in case of TimePension. However, the traditional contract with cliquet-style guarantees and TimePension have both comparably stable results, whereas the unit-linked payoffs are much more volatile. In addition to this, the results show that TimePension has more upside potential than the traditional contracts with the minimum interest rate guarantee. Thus, they show that stable payoffs do not have to be necessarily generated by interest rate guarantees, since TimePension leads to payoffs that are comparably stable and do not feature cliquet-style guarantees. In addition to this, TimePension has a higher upside potential than traditional products. However, TimePension features a different type of "guarantee", namely a predefined surplus distribution formula that generates stable payoffs. Their findings further show that the traditional with-profits life insurance contract is outperformed by the two benchmark products in all considered cases, expect the worst market scenarios in which the traditional scheme performs best (i.e., with respect to the $5 \%$ quantile of the size of pension benefits).

Faust, Schmeiser, and Zemp [28] analyze the performance of traditional participating life insurance contracts and compare it to the performance of a mutual fund and an exchange-traded fund. They, thereby, consider a participating life insurance contract with a cliquet-style minimum interest rate guarantee and a bonus distribution mechanism, which can be found in the German market. In comparison to this, the two funds are modeled without an investment guarantee and the exchange-traded fund is characterized by a lower cost structure than the mutual fund. In order to analyze the impact of the cliquet-style guarantee and the bonus distribution mechanism on the life insurance contract's investment result and for comparability reasons, the participating life insurance contract is decomposed in a term life insurance and a savings part with the focus on the latter. They further account for the life insurer's management discretion and for cross-subsidization effects between different cohorts of policyholders, which can play an important role in the balance sheet of a traditional life insurer. 
As a basis of the performance measurement, they calculate the final payoff distribution under the real-world risk measure $P$ of the three products considered, i.e., the participating life insurance contract (PLI) in the accumulation phase, the mutual fund (MF), and the exchange-traded fund (ETF). In order to account for the cross-subsidization effects, they distinguish between a participating life insurance contract, where the surplus fund has already been built up by previous policyholders ("PLI contract 3") and between a contract that starts with an empty surplus fund ("PLI contract 1"). Apart from providing some descriptive statistics, they first compare the mean payoff and several quantiles (median, and the quantiles for $5 \%, 25 \%, 75 \%$, and $95 \%$ ) of the payoff distribution for the four contracts, which are all highest for the exchange-traded fund. Next, they, inter alia, apply the risk measures Sharpe ratio, omega, and Sortino ratio by following Gatzert and Schmeiser [26]. The findings reveal that the three risk measures lead to the highest values (best) in case of the exchange-traded fund and the lowest values (worst) for the participating life insurance contract that starts with an empty surplus fund (PLI contract 1). In case of PLI contract 1, the surplus fund has first to be built up, through which later contract generations can benefit from. In turn, the participating life insurance contract starting with a high surplus fund (PLI contract 3 ) benefits from this surplus distribution mechanism and achieves higher values (better) for the considered risk measures than the mutual fund.

Thus, they show that cliquet-style guarantees considerably reduce performance compared to benchmark portfolios, but depending on the cost structure of the benchmark portfolios, participating life insurance can also be competitive, in case the participating life insurance contracts' buffer has already been built up (PLI contract 3). While Faust, Schmeiser, and Zemp [28] explicitly model different buffer stages, Jørgensen and Linnemann [27] assume the bonus smoothing to be "generation neutral", i.e., the buffer is kept on a certain level and a policyholder does not have to initially build it up. Guillén et al. [32] also consider the group level and do not distinguish between different policyholders (on policy level) having to build up the buffer.

Guillén et al. [32] analyze the performance of four Danish with-profits policies. The focus is laid on assessing the impact of an embedded minimum interest rate guarantee on the performance of the with-profits policies, i.e., the price of the interest rate guarantee is determined and expressed in lost returns. They thereby apply the performance measurement approach by Guillén et al. [31]. Hence, they model a with-profits strategy and compare it to an equivalent trivial benchmark strategy that invests a fixed proportion in stocks and bonds for the contract term, while keeping the risk of the two strategies equal for given risk measure, for which the expected shortfall is applied. Guillén et al. [32] model the with-profit policy's bonus distribution based on Grosen and Jørgensen [3] and they assume the bonus smoothing to be generation neutral (see, e.g., Jørgensen and Linnemann [27]) with an initial buffer level that equals the target buffer level for all contracts. So, they do not consider contracts that, first, have to build up the buffer and, thus, would be in a considerable disadvantage to later contract generations (see, e.g., Faust, Schmeiser, and Zemp [28]). They further consider the accumulation as well as decumulation phase over the product's contract term. On the basis of the median of final payoff distribution under the real-world measure $P$, they calculate the internal interest rates for each with-profits policy and the corresponding benchmark strategy.

Their findings reveal that all four with-profits policies that exist in the Danish insurance market are outperformed by the trivial benchmark strategies on the basis of a risk level of $95 \%$ with the expected shortfall as the relevant risk measure. They state that the financial loss, as a consequence of the interest 
rate guarantees, can reduce the return up to $0.87 \%$ per year compared to a benchmark strategy. Their results also show that the financial loss is larger for higher interest rate guarantees. They further show that there are no considerable differences among the performance of with-profit policies on the Danish life insurance market. It can further be seen in their analysis that minimum interest rate guarantees are only a meaningful product feature for policyholders that are extremely risk averse, e.g., at a risk level of 99.9\%.

Guillén et al. [32] further point out that the buffer level in Denmark in 2012 is lower for most of the life insurers than assumed in the paper and, thus, results would have to be worse than calculated in the paper. In addition to this, Guillén et al. [32] decompose the sources of underperformance of the with-profits contracts in three components denoted as the "law of the triple blow": (1) underperformance arises from the mechanism of participating in surplus; (2) risk premium for the interest rate guarantee has to be paid; and (3) policyholders become more risk averse after a relative loss compared to a benchmark. Mahlow, Schmeiser, and Wagner [33] analyze the performance of three types of pension schemes with focus on the German Riester products that are subsidized by the German government. First, they consider Riester life insurance contracts with a minimum interest rate guarantee and the right to receive surplus (cliquet-style guarantee); second, they include Riester fund products comprising a full money-back guarantee (point-to-point guarantee); and third, non-Riester fund products without any investment guarantee are considered. In order to compare the performance of these three types of pension schemes, they conduct a simulation analysis, where the contracts' specific cost structures are modeled in detail with a parameterization based on market data. While default risk is ignored, their model further takes surrender and mortality into account in the form of specific surrender and mortality rates that are applied for each year and which are also taken from market data. Since the focus is laid on the accumulation phase (pension period is ignored), the contracts' payoff distributions at the end of the accumulation phase are calculated under the real-world measure $P$ and are compared via performance measures, namely the Sharpe ratio and Sortino ratio.

The results in Mahlow, Schmeiser, and Wagner [33] show in respect to the contracts' comparative performance assessment that the non-Riester fund products (no guarantee), in particular its version with a low ETF cost structure, are clearly preferred according to the Sharpe ratio and Sortino ratio. The findings further rank the Riester fund products (point-to-point guarantee) as second best and the Riester life insurance contract (cliquet-style guarantee) as third, i.e., worst in the analysis with regard to the risk measures considered. The results further demonstrate the considerable stable payoffs in case of the Riester life insurance contract, which are substantially less volatile compared to the two other types of contracts.

\subsection{Point-to-Point Guarantees: The Case of Unit-Linked and Innovative Life Insurance}

We next focus on studying the performance of pension saving schemes featuring a point-to-point guarantee, such as a money-back guarantee, based on a selection of articles consisting of Gatzert and Schmeiser [26], Graf, Kling, and Russ [29], Gatzert [30], Guillén et al. [31], and again Mahlow, Schmeiser, and Wagner [33]. A comparative presentation of these articles is given in Table 5.

As can be seen from Table 5, all considered papers focus only on the policies' accumulation phases, except for Guillén et al. [31] that take the accumulation and decumulation phases into account. It can be further seen that fees and charges are ignored in case of Gatzert and Schmeiser [26], Gatzert [30], and Guillén et al. [31], whereas typical costs based on market data are included in the analyses by Graf, 
Kling, and Russ [29] and Mahlow, Schmeiser, and Wagner [33]. ${ }^{2}$ Except for Mahlow, Schmeiser, and Wagner [33], mortality and surrender effects are excluded in all considered articles.

While the results in Guillén et al. [31] exhibit that all considered Danish life-cycle pension strategies are outperformed by equivalent trivial benchmark strategies, Mahlow, Schmeiser, and Wagner [33] show that their non-Riester fund product without a guarantee outperforms the Riester fund product with a full money-back guarantee (point-to-point guarantee), which in turn outperforms the Riester life insurance contract with an interest rate guarantee and surplus participation (cliquet-style guarantee) according to the performance measures Sharpe ratio and Sortino ratio (see also Table 4).

Gatzert and Schmeiser [26] compare a fund investment with a point-to-point guarantee to a lookback guarantee and find that the results for the performance measures (Sharpe ratio, omega, and Sortino ratio) depend on the underlying fund characteristics and on how the guarantee is secured (CPPI vs. option-based approach). In accordance to this, the results in Graf, Kling, and Russ [29] also emphasize that the risk-return profiles are shaped by the money-back guarantee and the approach to secure the guarantee, which has a considerable impact on a contract's performance. Gatzert [30] contrasts the cases of a mutual fund investment including a money-back guarantee and no guarantee, and finds that the case without an investment guarantee leads to the highest values for the Sharpe ratio and omega, whereas the Sortino ratio is highest in case of a point-to-point investment guarantee. Thus, the findings in Gatzert and Schmeiser [26], Graf, Kling, and Russ [29], and Gatzert [30] indicate that it depends on the chosen risk and performance measure whether a contract with a money-back guarantee is outperformed by its benchmark or not.

2 See previous section for further details on Mahlow, Schmeiser, and Wagner [33]. 
Table 5. Point-to-point guarantees in unit-linked and innovative life insurance and their impact on performance: Insights from the literature.

\begin{tabular}{|c|c|c|c|c|c|}
\hline Article & Products and Guarantees & Some Analysis Characteristics & Performance Measurement & Some Key Findings & Outperformed * \\
\hline $\begin{array}{l}\text { Gatzert and } \\
\text { Schmeiser [26] }\end{array}$ & $\begin{array}{l}\text { - Mutual fund with two types of } \\
\text { guarantees: Interest rate guarantee } \\
\text { and lookback guarantee } \\
\text { - Guarantees are ensured via } \\
\text { two different approaches: First, risk } \\
\text { management instruments, i.e., price } \\
\text { of the guarantee under the risk- } \\
\text { neutral measure } Q \text { has to be paid; } \\
\text { Second, a constant proportion } \\
\text { portfolio (CPPI) managed fund } \\
\text { secures the guarantee }\end{array}$ & $\begin{array}{l}\text { - Only accumulation phase } \\
\text { - Investment portfolio is constructed as } \\
\text { mean-variance efficient and } \\
\text { composed of indices for stocks, bond, } \\
\text { real estate, and the money market } \\
\text { - Mortality, surrender, and costs } \\
\text { are not taken into account (besides } \\
\text { guarantee costs) }\end{array}$ & $\begin{array}{l}\text { - Payoff distribution is calculated } \\
\text { under the real-world measure } \\
P \text { for the mutual fund } \\
\text { (conventional and CPPI } \\
\text { managed fund) and for } \\
\text { two types of guarantees } \\
\text { (interest rate and lookback) } \\
\text { - Performance is measured via } \\
\text { Sharpe ratio, omega and } \\
\text { Sortino ratio } \\
\text { - Tests for stochastic dominance } \\
\text { (first, second, and third degree) } \\
\text { are conducted } \\
\text { - In case of conventional fund: } \\
\text { Guarantee costs are calculated via } \\
\text { risk-neutral valuation (under the } \\
\text { risk-neutral measure } Q \text { ) and set } \\
\text { equal for the two types of } \\
\text { guarantees (interest rate and } \\
\text { lookback) to ensure comparability }\end{array}$ & $\begin{array}{l}\text { Case } 1 \text { (CPPI): Minimum interest rate } \\
\text { guarantee of } 0 \% \text { (money-back guarantee) } \\
\text { vs. lookback guarantee with CPPI managed } \\
\text { fund (implicit guarantee costs); Results: fund } \\
\text { with interest rate guarantee has higher } \\
\text { expected maturity payout, higher standard } \\
\text { deviation, higher probability of large } \\
\text { maturity payouts, higher omega and } \\
\text { Sortino ratio, and lower Sharpe ratio } \\
\text { - Case } 2 \text { (Conventional fund): Minimum } \\
\text { interest rate guarantee vs. lookback } \\
\text { guarantee for a conventional underlying } \\
\text { fund (guarantee cost are set to be equal); } \\
\text { Results: fund with lookback guarantee has } \\
\text { higher probability that value of fund at } \\
\text { maturity is lower than guaranteed payout, } \\
\text { higher expected maturity payout, lower } \\
\text { standard deviation, higher Sharpe ratio, } \\
\text { whereas the omega and Sortino ratio depend } \\
\text { on the parameters of the underlying fund } \\
\text { - In no case a first-, second-, or third-order } \\
\text { stochastic dominance is found } \\
\text { - Lookback guarantee is very expensive for a } \\
\text { fund with a high volatility }\end{array}$ & $\begin{array}{l}\text { Yes/no (depending } \\
\text { on the performance } \\
\text { measure) }\end{array}$ \\
\hline
\end{tabular}


Table 5. Cont.

\begin{tabular}{|c|c|c|c|c|c|}
\hline Article & Products and Guarantees & Some Analysis Characteristics & Performance Measurement & Some Key Findings & Outperformed * \\
\hline $\begin{array}{l}\text { Graf, Kling, } \\
\text { and Russ [29] }\end{array}$ & $\begin{array}{l}\text { - Generic old-age provision products } \\
\text { with and without a money-back } \\
\text { guarantee (typical products for the } \\
\text { insurance market, i.e., in Germany) } \\
\text { - Considered products without any } \\
\text { investment guarantee: equity fund, } \\
\text { balanced and life-cycle fund } \\
\text { - Considered products with a money- } \\
\text { back guarantee: Static option based } \\
\text { product, zero-bond plus } \\
\text { underlying, constant proportion } \\
\text { portfolio insurance on client } \\
\text { individual basis (iCPPI), CPPI } \\
\text { implemented in a mutual fund } \\
\text { (CPPI high watermark) }\end{array}$ & $\begin{array}{l}\text { - Only accumulation phase } \\
\text { - Several product specific charges } \\
\text { are taken into account } \\
\text { - Mortality and surrender } \\
\text { effects are ignored } \\
\text { - In addition to modeling the } \\
\text { future maturity payoff, products } \\
\text { are compared by means of } \\
\text { sample illustrations and back- } \\
\text { testing techniques } \\
\text { - Single and regular premium } \\
\text { payments are compared }\end{array}$ & $\begin{array}{l}\text { Maturity payoff distribution is } \\
\text { calculated under the real-world } \\
\text { measure } P \text { (for contract terms } \\
\text { of } 12 \text { and } 30 \text { years) } \\
\text { - In case of money-back guarantee } \\
\text { is secured via options: guarantee } \\
\text { price is determined under the } \\
\text { risk-neutral measure } Q \text { and } \\
\text { subtracted from the underlying } \\
\text { fund in terms of guarantee fees } \\
\text { (option based product) } \\
\text { - Distribution of maturity benefits } \\
\text { are compared based on: (1) risk- } \\
\text { return profiles including the } \\
\text { expected return and several } \\
\text { quantiles ( } 5 \%, 25 \%, 50 \%, 75 \%, \\
\text { and } 95 \% \text { ); (2) internal rate of return } \\
\text { (IRR); (3) risk measures: shortfall } \\
\text { probability that the IRR falls below } \\
\text { a threshold of } 0 \%, 0.01 \% \text {, and } 2 \% \text {; } \\
\text { expected shortfall (contingent on a } \\
\text { return less than } 0 \% \text { ); conditional } \\
\text { tail expectation (CTE) at } 95 \% \text { level } \\
\text { of IRR; and (4) first order } \\
\text { stochastic dominance is tested for }\end{array}$ & $\begin{array}{l}\text { - Repeated back-testing in the time interval } 1973 \text { to } 1999 \\
\text { for a contract term of } 12 \text { years reveals internal rates of } \\
\text { return of strict greater than } 0 \% \text { for all considered } \\
\text { products, i.e., with and without a money-back guarantee } \\
\text { - Results do not show first order dominance of one product } \\
\text { compared to another, i.e., a product's risk-return profile } \\
\text { has to suit a customer's degree of risk aversion } \\
\text { - Equity fund without any investment } \\
\text { guarantee exhibits the highest variability } \\
\text { of the maturity payoff (as expected) } \\
\text { - Different approaches to provide a money-back guarantee } \\
\text { (static option based product, zero-bond plus underlying, } \\
\text { iCPPI, CPPI high watermark) result in considerably } \\
\text { different risk-return profiles, inter alia (for single } \\
\text { premiums and a } 12 \text { year term): (1) iCPPI's upside } \\
\text { potential resembles the equity fund, but at the cost of a } \\
\text { median maturity payoff close to } 0 \% \text {; (2) static option } \\
\text { based product exhibits a lower upside potential than } \\
\text { the iCPPI; (3) zero-bond plus underlying results } \\
\text { in the least volatile final payoffs; (4) CPPI high } \\
\text { watermark leads to the lowest expected return } \\
\text { - Regular premiums ( } v s \text {. single premium): } \\
\text { iCPPI payoff median increases and is } \\
\text { - Contract term of } 30 \text { ( } v s .12 \text { ) years: Expected shortfall is } \\
\text { higher for products with money-back guarantee }\end{array}$ & $\begin{array}{l}\text { Yes/no } \\
\text { (depending on } \\
\text { the performance } \\
\text { measure) }\end{array}$ \\
\hline
\end{tabular}


Table 5. Cont.

\begin{tabular}{|c|c|c|c|c|c|}
\hline Article & Products and Guarantees & Some Analysis Characteristics & Performance Measurement & Some Key Findings & Outperformed * \\
\hline Gatzert [30] & $\begin{array}{l}\text { - Mutual fund with and without an } \\
\text { investment guarantee (point-to- } \\
\text { point guarantee including a money- } \\
\text { back guarantee) and different } \\
\text { premium payment schemes }\end{array}$ & $\begin{array}{l}\text { - Investment is } 100 \% \text { in stocks } \\
\text { - Only accumulation phase } \\
\text { - Costs, mortality, and surrender } \\
\text { are not taken into account } \\
\text { - Annual savings are compared to } \\
\text { upfront savings, each for the } \\
\text { case without a guarantee, with } \\
\text { guarantee for upfront costs, and } \\
\text { with guarantee with an annual } \\
\text { percentage fee }\end{array}$ & $\begin{array}{l}\text { Follow Gatzert and Schmeiser [26] } \\
\text { for measuring performance, i.e., } \\
\text { final payoff distribution is } \\
\text { determined under the real-world } \\
\text { measure } P \text { and compared with the } \\
\text { risk measures Sharpe ratio, omega, } \\
\text { and Sortino ratio } \\
\text { - Guarantee costs are calculated } \\
\text { under the risk-neutral measure } Q \\
\text { and kept equal to make different } \\
\text { settings comparable }\end{array}$ & $\begin{array}{l}\text { - Expected final payoffs minus the premium } \\
\text { payments is highest in case of no guarantee } \\
\text { along with the highest volatility } \\
\text { - The case without an investment guarantee leads } \\
\text { to the highest values for the Sharpe ratio and } \\
\text { omega (which represent a less risk-averse decision } \\
\text { maker), whereas the Sortino ratio is highest } \\
\text { in case of a point-to-point investment guarantee } \\
\text { - Values for Sharpe ratio and omega decrease with an } \\
\text { increasing investment guarantee level, whereas Sortino } \\
\text { ratio increase for higher guarantee levels }\end{array}$ & $\begin{array}{l}\text { Yes/no } \\
\text { (depending on } \\
\text { the performance } \\
\text { measure) }\end{array}$ \\
\hline
\end{tabular}


Table 5. Cont.

\begin{tabular}{|c|c|c|c|c|c|}
\hline Article & Products and Guarantees & Some Analysis Characteristics & Performance Measurement & Some Key Findings & Outperformed * \\
\hline Guillén et al. [31] & $\begin{array}{l}\text { Danish life-cycle pension strategies } \\
\text { of the year 2007: } 5 \text { products from } \\
\text { the largest companies in Denmark } \\
\text { (Danica, PFA, Nordea, and SEB } \\
\text { with Market Pension and } \\
\text { TimePension) and two trivial } \\
\text { strategies (both unit-linked in } \\
\text { accumulation phase and one is } \\
\text { also unit-linked in payout phase) } \\
\text { are considered } \\
\text { - Contracts' investment process and } \\
\text { return mechanisms are transparent, } \\
\text { i.e., known to the policyholders at } \\
\text { inception of the contract } \\
\text { - Products are compared without an } \\
\text { investment guarantee and a point- } \\
\text { to-point money-back guarantee is } \\
\text { considered in form of fair } \\
\text { guarantee prices }\end{array}$ & $\begin{array}{l}\text { Accumulation and decumulation } \\
\text { phases are considered with } \\
\text { constant and decreasing } \\
\text { annuities; accumulation phase } \\
\text { starts at the age of } 30 \text { with } \\
\text { yearly premiums of } 10 \text { until the } \\
\text { age of } 60 \text {, then constant } \\
\text { annuities pay an annuity of } \\
10 \text { per year until the age of } \\
90 \text { and decreasing annuities pay } \\
\text { an annuity of } 20 \text { for } 10 \text { years } \\
\text { and afterwards } 5 \text { for } 20 \text { years, } \\
\text { i.e., until the age of } 90 \\
\text { - Sum of premiums equals sum of } \\
\text { annuity payments (for both } \\
\text { types of annuities) and wealth at } \\
\text { the age of } 90 \text { is studied } \\
\text { - Mortality, surrender and costs } \\
\text { are not taken into account }\end{array}$ & $\begin{array}{l}\text { - Contract's payoff distribution at } \\
\text { maturity (i.e., at age 90) is calculated: } \\
\text { (1) under the real-world measure } P \text { to } \\
\text { determine the value at risk (VaR) (or } \\
\text { conditional tail expectation (CTE)) on } \\
\text { the } 5 \% \text { level based on the distribution's } \\
\text { median (or mean); (2) under the risk- } \\
\text { neutral measure } Q \text { to determine the fair } \\
\text { price of the point-to-point guarantee at } \\
\text { maturity (to provide annuity payments } \\
\text { until maturity and not to have a negative } \\
\text { payoff at age } 90 \text { ) } \\
\text { - Based on one of these three risk } \\
\text { measures (VaR, CTE, fair price), an } \\
\text { equivalent trivial benchmark strategy } \\
\text { with a fixed stock portion throughout } \\
\text { the contract term with the same risk is } \\
\text { determined } \\
\text { - Internal rates of return per year are } \\
\text { calculated based on the median (or } \\
\text { mean) of the final wealth distribution } \\
\text { under the real-world measure } P \\
\text { - Difference of internal rates of return for } \\
\text { the product and the benchmark is } \\
\text { considered as yearly financial loss of } \\
\text { the pension strategy (or gain) }\end{array}$ & $\begin{array}{l}\text { All trivial benchmark strategies with a } \\
\text { constant stock portion (which contain } \\
\text { the same risk as the pension product } \\
\text { according to a certain risk measure) } \\
\text { outperform the considered life-cycle pension } \\
\text { strategies by the largest Danish insurance } \\
\text { companies (Danica, PFA, Nordea, and SEB) }\end{array}$ & $\begin{array}{l}\text { - Yes (all pension } \\
\text { strategies are } \\
\text { outperformed } \\
\text { by trivial } \\
\text { benchmark } \\
\text { portfolios } \\
\text { including the } \\
\text { cases where all } \\
\text { strategies are } \\
\text { equipped with a } \\
\text { money-back } \\
\text { guarantee) }\end{array}$ \\
\hline
\end{tabular}


Table 5. Cont.

\begin{tabular}{|c|c|c|c|c|c|}
\hline Article & Products and Guarantees & Some Analysis Characteristics & Performance Measurement & Some Key Findings & Outperformed * \\
\hline $\begin{array}{l}\text { Mahlow, Schmeiser, } \\
\text { and Wagner [33] }\end{array}$ & - See Table 4 & - See Table 4 & - See Table 4 & $\begin{array}{l}\text { Performance measures (Sharpe ratio and } \\
\text { Sortino ratio) are best for the non-Riester fund } \\
\text { products (no guarantee), second best for the } \\
\text { Riester fund products with a full money-back } \\
\text { guarantee (point-to-point guarantee), and worst } \\
\text { for the Riester life insurance contracts with an } \\
\text { interest rate guarantee and surplus participation } \\
\text { (cliquet-style guarantee) }\end{array}$ & $\begin{array}{l}\text { - Yes/no } \\
\text { (depending on } \\
\text { the benchmark) }\end{array}$ \\
\hline
\end{tabular}

Notes: * indicates that the product with a point-to-point guarantee is outperformed by the considered benchmarks products (see column "some key findings" for more details). 
Moreover, we present the considered articles in more detail, while for Mahlow, Schmeiser, and Wagner [33] we refer to the previous section.

Gatzert and Schmeiser [26] analyze the impact of investment guarantees on the performance of a mutual fund. They thereby consider two types of guarantees, namely a lookback guarantee and an interest rate guarantee. The latter ensures a minimum interest rate on the premiums paid and is evaluated at maturity which, thus, represents a point-to-point guarantee at maturity. They further distinguish between two cases for ensuring a guarantee. First, a constant proportion portfolio insurance (CPPI) strategy secures a guaranteed payoff and does not require a separate payment for guarantee costs, since they are implicitly contained in the strategy. Second, a conventional fund is considered, where the guarantee price calculated under the risk-neutral $Q$ has to be paid for risk management instruments. In order to compare the two types of guarantees, the mutual funds' payoff distributions at maturity are calculated under the real-world measure $P$. In case of the conventional fund, the fair guarantee prices are set to be equal, i.e., the interest rate guarantee level is calibrated such the guarantee prices of the interest rate guarantee and the lookback guarantee are equal. The payoff distributions are evaluated with different risk measures including omega, the Sharpe and Sortino ratio. They further test for first, second, and third degree stochastic dominance.

In case of the CPPI managed fund, a minimum interest rate guarantee of $0 \%$, which resembles a point-to-point money-back guarantee is compared to a lookback guarantee. The mutual fund equipped with the money-back guarantee leads to a higher expected maturity payoff with a higher standard deviation compared to the lookback guarantee. The performance measures indicate a higher Sharpe ratio for the money-back guarantee and lower values for the Sortino ratio and omega compared to the lookback guarantee. In case of the conventional fund, the guarantee costs for both types of guarantees are set equal by adjusting the interest rate guarantee level which is, thus, greater than zero. The results show a higher expected payoff for the lookback guarantee with a lower standard deviation compared to the interest rate guarantee for equal guarantee costs. The results of the three risk measures depend on the riskiness of the underlying fund. While all three risk measures are higher for the lookback guarantee for a less risky underlying portfolio, the Sortino ratio and omega are higher for the interest rate guarantee for the more risky portfolio. The findings further show that a lookback guarantee is very expensive for an underlying portfolio with a high volatility. Furthermore, in no case a first, second, or third degree stochastic dominance is found.

Graf, Kling, and Russ [29] compare the performance of seven old-age provision products on the basis of risk-return profiles and downside risk measures. Each of these seven products represent a category of a typical pension saving scheme for the accumulation phase, e.g., in the German insurance market. On the one hand, they consider contracts without any type of investment guarantee, i.e., three out of the seven contracts are either a pure equity investment (100\% stocks and denoted as equity fund) or a portfolio consisting of stocks and bonds, where the stock portion is constant over time (50\% stocks and denoted as balanced fund) or decreasing over time in case of the life-cycle fund (starting with $100 \%$ stocks). On the other hand, four contracts are considered that feature a money-back guarantee at maturity (point-to-point guarantee), which is provided in various ways: (1) an equity fund investment is combined with the purchase of a corresponding option that ensures the point-to-point guarantee (option based product); (2) single premium or contract's account value is invested in zero-bonds and an equity fund, where the money-back guarantee is achieved by the zero-bond investment (zero-bond plus underlying); 
(3) the contract's account value is dynamically reallocated between an equity fund (risky asset) and bond investment (risk-free asset) according to a policyholder's individual constant proportion portfolio insurance strategy (iCPPI); and (4) single premium or contract's account value is invested in a mutual fund featuring a CPPI strategy to secure the money-back guarantee (CPPI high watermark). While the paper aims to support a customer's decision-making process toward the right pension saving product in accordance with the customer's needs, it also compares pension saving products with and without guarantees. The paper thus illustrates and assesses the impact of a money-back guarantee on the performance of pension saving schemes, in particular different ways of ensuring this guarantee are compared.

In order to compare the contracts, Graf, Kling, and Russ [29] calculate the maturity payoff distribution under the real-world measure $P$ (for contract terms of 12 and 30 years). In case of the option based product, i.e., where the money-back guarantee is secured via options, the guarantee price is determined under the risk-neutral measure $Q$ and subtracted from the underlying fund in terms of guarantee fees. The resulting distributions of the contracts' maturity benefits are then compared based on risk-return profiles including the expected return and several quantiles, the internal rate of return (IRR), and downside risk measures. Furthermore, they test for first order stochastic dominance.

The results show that the impact of a money-back guarantee on the performance of the saving product varies depending on how the guarantee is secured. First, they do not find one superior pension scheme with respect to first order stochastic dominance, i.e., products have different risk-return profiles that suit different customer's needs. A ranking for single premium contracts (with a contract term of 12 years) in regard to the expected maturity payoff starts with the equity fund (without guarantee) that generates the highest expected return, followed by the products with guarantees, i.e., the iCPPI, the option based product, the zero-bond plus underlying, and lastly the CPPI high watermark. However, when comparing the payoffs' medians this ranking changes considerably and starts with the zero-bond plus underlying, followed by the CPPI high watermark, the option-based product, and lastly the iCPPI. In turn, the iCPPI with the money-back guarantee has an upside potential that is comparable to the equity fund that features no guarantee.

Gatzert [30] studies the performance of a mutual fund for different premium payment schemes and for various levels of a point-to-point investment guarantee. In the model framework, an investment of $100 \%$ stocks is considered and the portfolio's final payoff distribution is calculated under the real-world measure $P$, while guarantee prices are determined under the risk-neutral measure $Q$ and kept constant for various cases to make them comparable. For evaluating the performance, Gatzert [30] follows Gatzert and Schmeiser [26] and applies the preference-dependent performance measures Sharpe ratio, omega, and Sortino ratio to the simulated payoff distribution at maturity. Gatzert [30] highlights that the performance measures that are being applied to evaluate risk-return profiles have to be in line with the decision makers' risk preferences. The Sortino ratio represents a measure for more risk-averse policyholder, since the downside risk is thereby explicitly taken into account, while the Sharpe ratio is rather for less risk-averse policyholders and omega is in between these two.

The results in Gatzert [30] contrasting the cases with and without the point-to-point investment guarantee show that the expected final net payoffs exhibit the highest value and the highest volatility in case of no guarantee, which does then not include any downside protection. Thus the findings for the case of no guarantee are preferred by policyholders that decide on the basis of the Sharpe ratio or omega, since their values are higher for these cases than the Sortino ratio. In contrast to this, the Sortino ratio is highest 
in case of a point-to-point guarantee, e.g. a money-back guarantee. The findings further reveal that the Sortino ratios increase with an increasing value of the point-to-point guarantee, whereas the Sharpe ratios and omegas decrease in the corresponding cases.

Guillén et al. [31] analyze and compare the performance of pension strategies that are available in the Danish market and they thereby introduce a new approach to measure the products' performance. In total, seven different products are considered. Five contracts are products by the largest insurers in Denmark, namely Danica, PFA, Nordea, and SEB (with Market Pension and TimePension) and two contracts are trivial investment strategies with a fixed stock portion for the accumulation phase and the whole contract term, respectively. For each pension strategy, the investment process and return mechanism is given by a mathematical algorithm in case of TimePension or simply by the stock portion function over time in case of the six other strategies, i.e., the products are transparent to the policyholders. The model framework does further take the accumulation and decumulation phase into account, where premiums are paid for 30 years (from age 30 to 60) and afterwards annuity payments are received either as constant or decreasing annuities for 30 years (from age 60 to 90). Mortality and surrender is thereby ignored. These cash flows are fixed a priori, i.e., the premiums are set to 10 per year (for 30 years) and the annuity payments are 10 per year in case of constant annuities (for 30 years), and in case of decreasing annuities the payments are 20 for 10 years, followed by 5 for 20 years. While thus the sum of premium payments is set equal to the sum of annuity payments (for both types of annuities), the final wealth at maturity (at age 90) has to be studied and can also be negative meaning that the annuity payments to the policyholders would have to be discontinued prior to maturity in such a scenario.

In order to assess a contract's performance, the yearly internal rate of return is calculated. In a next step, this rate is compared to the internal rate of return of an equivalent trivial benchmark strategy. A trivial benchmark is given by an investment strategy with a fixed stock portion (and the remainder is invested risk-free) with the same amount of risk as compared to the considered pension strategy expressed by a relevant risk measure. Thus, the contracts' payoff distributions at maturity are calculated. First, this is done under the real-world measure $P$ to determine the two risk measures value at risk and conditional tail expectation by means of the distributions' medians and means (at a 5\% level). Second, the fair price of a point-to-point guarantee that ensures the ability for annuity payments until maturity (i.e., that the final wealth is not negative) is calculated under the risk-neutral measure $Q$. For these three risk measures, the equivalent trivial benchmark strategies are determined. Finally, the difference of the yearly internal rates of return for the pension strategy and its equivalent benchmark is considered as financial loss per year. The results show that all considered pension saving strategies are outperformed by means of the yearly financial loss by their benchmark strategies.

\section{Summary and Concluding Remarks}

In this paper, we provide a presentation of selected studies that investigate the performance of pension saving contracts with investment guarantees and which thereby (explicitly or implicitly) study the impact of these guarantees on the performance of the pension products. In particular, we focus on two types of guarantees, namely the cliquet-style guarantees that can typically be found in traditional life insurance contracts, and point-to-point guarantees, such as a money-guarantee that is often applied in innovative life insurance financial products. 
The review of the considered studies shows that they can be classified in two groups with respect to their performance measurement approaches. Articles belonging to the first group simulate the pension contracts' payoff distribution under the real-world measure $P$ (including the guarantees under study) and evaluate the resulting distributions by means of risk and performance measures. Apart from comparing payoff distributions of contracts with and without guarantees in the first approach, articles in the second group contrast internal rates of return of the considered pension product with internal rates of return of an equivalent trivial benchmark strategy, which is composed of stocks and bonds with fixed portions over time. Equivalent relates here to the calibration of the benchmark portfolio that has to lead to the same risk as the pension product for a predefined risk measure.

Overall, the results show that guarantees in pension saving products are expensive in the sense that they can reduce a contract's performance, which considerably depends on the type of guarantee. In addition to this, financial guarantees have a substantial impact on the characteristics of risk-return profiles. In particular, the studies show that not only the guarantee itself, but also the way the guarantee is secured, e.g., via a CPPI strategy or by risk management methods such as options, plays an important role in shaping a contract's risk-return profile along with its risk and performance measures. Furthermore, results differ for the two considered types of guarantees. In case of the point-to-point guarantees, mostly analyzed in the form of a money-back guarantee, results do not provide a uniform picture, i.e., the articles' findings demonstrate that it depends on the particular risk and performance measure whether a contract featuring a money-back guarantee is outperformed by a benchmark contract or not. In contrast to this, the results of the considered articles mostly agree with respect to cliquet-style guarantees and exhibit that traditional pension saving contracts, including a cliquet-style guarantee, are, in general, outperformed by various benchmark products. This also holds true for both performance measurement approaches. Here, benchmark products comprise an equivalent trivial benchmark portfolio as stated above and also further pension saving products as typical life insurance financial products. The considered studies further exhibit that the analyses mainly focus on the contracts' accumulation phases, whereas a comprehensive study including the accumulation and decumulation phase is only conducted by two papers, which might further be interesting for future research.

In summary, we provide a traditional literature review of studies that assess the impact of typical guarantees on the performance of pension saving strategies, while we thereby focus on cliquet-style guarantees and point-to-point guarantees. Results show that guarantees can have a considerable impact on shaping a pension saving contract's payoff distribution and on the overall contract's financial performance. While customers should be aware of that and knowingly choose guarantees that fit their needs, insurers should provide guarantees when designing new life insurance financial products, for which customers are knowingly willing to accept a reduction in performance.

\section{Acknowledgments}

The author would like to thank two anonymous referees for valuable comments and suggestions on an earlier version of the paper.

\section{Conflicts of Interest}

The author declares no conflict of interest. 


\section{References}

1. Briys, E.; de Varenne, F. On the risk of insurance liabilities: Debunking some common pitfalls. J. Risk Insur. 1997, 64, 673-694.

2. Grosen, A.; Jørgensen, P.L. Fair valuation of life insurance liabilities: The impact of interest rate guarantees, surrender options and bonus policies. Insurance: Math. Econ. 2000, 26, 37-57.

3. Grosen, A.; Jørgensen, P.L. Life insurance liabilities at market value: an analysis of insolvency risk, bonus policy, and regulatory intervention rules in a barrier option framework. J. Risk Insurance 2002, 69, 63-91.

4. Tiong, S. Valuing equity-indexed annuities. N. Am. Actuarial J. 2000, 4, 149-170.

5. Milevsky, M.; Posner, S. The titanic option: Valuation of the guaranteed minimum death benefit in variable annuities and mutual funds. $J$. Risk Insurance 2001, 68, 93-128.

6. Hansen, M.; Miltersen, K.R. Minimum rate of return guarantees: The danish case. Scand. Actuarial J. 2002, 2002, 280-318.

7. Gerber, H.U.; Shiu, E.S.W. Pricing lookback options and dynamic guarantees. N. Am. Actuarial J. 2003, 7, 48-66.

8. Hardy, M. Investment Guarantees: Modeling and Risk Management for Equity-Linked Life Insurance; John Wiley \& Sons: Hoboken, NJ, USA, 2003.

9. Tanskanen, A.J.; Lukkarinen, J. Fair valuation of path-dependent participating life insurance contracts. Insurance: Math. Econ. 2003, 33, 595-609.

10. Barbarin, J.; Devolder, P. Risk measure and fair valuation in life insurance. Insurance: Math. Econ. 2005, 37, 297-323.

11. Siu, T.K. Fair Valuation of participating policies with surrender options and regime switching. Insurance: Math. Econ. 2005, 37, 533-552.

12. Guillén, M.; Jørgensen, P.L.; Nielsen, J.P. Return smoothing mechanisms in life and pension insurance: Path-dependent contingent claims. Insurance: Math. Econ. 2006, 38, 229-252.

13. Gatzert, N.; Kling, A. Analysis of participating life insurance contracts: A unification approach. J. Risk Insurance 2007, 74, 547-570.

14. Ledlie, M.C.; Corry, D.P.; Finkelstein, G.S.; Ritchie, A.J.; Su, K.; Wilson, D.C.E. Variable annuities. Br. Actuarial J. 2008, 14, 327-389.

15. Branger, N.; Mahayni, A.; Schneider, J.C. On the optimal design of insurance contracts with guarantees. Insurance: Math. Econ. 2010, 46, 485-492.

16. Dong, Y. Fair valuation of life insurance contracts under a correlated jump diffusion model. ASTIN Bull. 2011, 41, 429-447.

17. Kling, A.; Ruez, F.; Russ, J. The impact of stochastic volatility on pricing, hedging, and hedge efficiency of withdrawal benefit guarantees in variable annuities. ASTIN Bull. 2011, 41, 511-545.

18. Schmeiser, H.; Wagner, J. A joint valuation of premium payment and surrender options in participating life insurance contracts. Insurance: Math. Econ. 2011, 49, 580-596.

19. Goecke, O. Pension saving schemes with return smoothing mechanism. Insurance: Math. Econ. 2013, 53, 678-689.

20. Gatzert, N.; Schmeiser, H. New Life Insurance Financial Products, In Handbook of Insurance, 2nd ed.; Dionne, G., Ed.; Springer: New York, NY, USA, 2013; pp. 1061-1095. 
21. Broeders, D.; Chen, A.; Koos, B. A utility-based comparison of pension funds and life insurance companies under regulatory constraints. Insurance: Math. Econ. 2011, 49, 1-10.

22. Gatzert, N.; Huber, C.; Schmeiser, H. On the valuation of investment guarantees in unit-linked life insurance: A customer perspective. Geneva Papers Risk Insurance-Issues Pract. 2011, 36, 3-29.

23. Gatzert, N.; Holzmüller, I.; Schmeiser, H. Creating customer value in participating life insurance. J. Risk Insurance 2012, 79, 645-670.

24. Maurer, R.; Rogalla, R.; Siegelin, I. Participating payout life annuities: lessons from germany. ASTIN Bull. 2013, 43, 159-187.

25. Bohnert, A.; Born, P.; Gatzert, N. Dynamic hybrid products in life insurance: Assessing the policyholders' viewpoint. Insurance: Math. Econ. 2014, 59, 87-99.

26. Gatzert, N.; Schmeiser, H. Pricing and performance of mutual funds: Lookback versus interest rate guarantees. J. Risk 2009, 11, 31-49.

27. Jørgensen, P.L.; Linnemann, P. A Comparison of three different pension savings products with special emphasis on the payout phase. Ann. Actuarial Sci. 2012, 6, 137-152.

28. Faust, R.; Schmeiser, H.; Zemp, A. A performance analysis of participating life insurance contracts. Insurance: Math. Econ. 2012, 51, 158-171.

29. Graf, S.; Kling, A.; Russ, J. Financial planning and risk-return profiles. Eur. Actuarial J. 2012, 2, $77-104$.

30. Gatzert, N. On the relevance of premium payment schemes for the performance of mutual funds with investment guarantees. J. Risk Financ. 2013, 14, 436-452.

31. Guillén, M.; Nielsen, J.P.; Pérez-Marín, A.M.; Petersen, K.S. Performance measurement of pension strategies: A case study of danish life cycle products. Scand. Actuarial J. 2013, 2013, 258-277.

32. Guillén, M.; Konicz, A.K.; Nielsen, J.P.; Pérez-Marín, A.M. Do not pay for a danish interest guarantee. The law of the triple blow. Ann. Actuarial Sci. 2013, 7, 192-209.

33. Mahlow, N.; Schmeiser, H.; Wagner, J. A Performance Analysis of Riester Pension Schemes, Working Paper; University of St. Gallen: St. Gallen, Switzerland, 2013.

34. Web of Science. Available online: www.webofknowledge.com (accessed 6 January 2015).

35. Google Scholar. Available online: scholar.google.com (accessed 6 January 2015).

36. Faust, R.; Schmeiser, H.; Zemp, A. A performance analysis of participating life insurance contracts. Z. Gesamte Versicher. 2011, 100, 707-718.

37. Bohnert, A.; Gatzert, N. Analyzing surplus appropriation schemes in participating life insurance from the insurer's and the policyholder's perspective. Insurance: Math. Econ. 2012, 50, 64-78.

38. Kling, A.; Richter, A.; Russ, J. The interaction of guarantees, surplus distribution, and asset allocation in with-profit life insurance policies. Insurance: Math. Econ. 2007, 40, 164-178.

39. Linnemann, P.; Bruhn, K.; Steffensen, M. A Comparison of modern investment-linked pension savings products. Ann. Actuarial Sci. 2015, 9, 72-84.

(C) 2015 by the authors; licensee MDPI, Basel, Switzerland. This article is an open access article distributed under the terms and conditions of the Creative Commons Attribution license (http://creativecommons.org/licenses/by/4.0/). 